\title{
Ormancılık çalışmalarını kamuoyuna duyuracak etkili kitle iletişim araçlarına yönelik mevcut durum analizi (Isparta OBM örneği)
}

Present situation analysis of effective mass media announcing forestry activities to the public (the case of Isparta RDF in Turkey)

Arif KAYACAN ${ }^{1}$ iD

Süleyman ALKAN ${ }^{1}$ (DD

Ersin YILMAZ1

Yunus BAYİR ${ }^{1}$

Uğur Melih ALKAN ${ }^{1}$

${ }^{1}$ Batı Akdeniz Ormancılık Araștırma Enstitüsü Müdürlüğ̈̈, Antalya

Sorumlu yazar (Corresponding author) Ersin YILMAZ

eyilmaz33@gmail.com

Geliş tarihi (Received)

21.02.2020

Kabul tarihi (Accepted)

06.04 .2020

Sorumlu editör (Corresponding editor)

Güven KAYA

guvenkaya@ogm.gov.tr

Atıf (To cite this article): KAYACAN, A, ALKAN, S, YILMAZ, E, BAYIR, Y, ALKAN, U . (2020). Ormancılık çalışmalarını kamuoyuna duyuracak etkili kitle iletişim araçlarına yönelik mevcut durum analizi (Isparta OBM örneği). Ormancılık Arastırma Dergisi , 7 (2), 131-146. DOI: https://doi.org/10.17568/ogmoad.692363

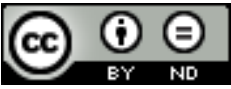

Creative Commons Atıf . Türetilemez 4.0 Uluslar Uüretilemez 4.0 Uluslarar
Lisansı ile lisanslanmıștır.

\section{Öz}

$\mathrm{Bu}$ çalışmada mevcut üstünlükler, zayıflıklar, fırsatlar ve tehditler ortaya konularak, Isparta Orman Bölge Müdürlüğündeki (OBM) ormancılık çalışmalarını kamuoyuna duyuracak etkili kitle iletişim araçlarının belirlenmesi ve önceliklendirilmesi işlemi gerçekleştirilmiştir. Böylece bu alandaki kitle iletişim araçlarının geliştirilmesine yönelik öneriler geliştirilmiştir. Araştırmanın ana amacı; Isparta OBM'de ormancılık çalışmalarını kamuoyuna duyuracak etkili kitle iletişim araçlarının belirlenmesine yönelik üstünlükleri, zayıflıkları, fırsatları ve tehditleri ortaya koymaktır. Diğer amaçlar ise araştırma alanında kitle iletişim araçları konusundaki mevcut yapıyı incelemek, kitle iletişim araçlarına yönelik potansiyelleri ve kısıtları belirlemek ve buna yönelik mevcut yapıyı iyileştirebilmek için öneriler geliştirmektir. Araştırmada SWOT (Üstünlükler, Zayıflıklar, Fırsatlar ve Tehditler) çözümlemeleri ile Çok Kriterli Karar Verme (ÇKKV) tekniklerini bir araya getiren bir melez teknik olan R'WOT (Ranking Tekniği + SWOT Çözümlemeleri + Doğrusal Kombinasyon Tekniğii) tekniği kullanılmıştır. Bu teknik SWOT gruplarının ve her bir SWOT grubu içindeki SWOT faktörlerine ait önceliklerin ve önem sırasının belirlenmesinde, Siralama tekniği ve Doğrusal Kombinasyon tekniğini birlikte kullanan kombine bir yaklaşımdır. Kullanılan R'WOT tekniği, farklı karar verme durumları için uygun bir araçtır. Bu örnek uygulama çalışması da sunulan metodolojinin faydalılı̆̆ını göstermiştir.

Anahtar Kelimeler: Katılım, çok kriterli karar verme, R'WOT, kitle iletişim araçları, Isparta, Orman Bölge Müdürlüğü (OBM)

\section{Abstract}

In this study, the existing advantages, weaknesses, opportunities and threats were revealed, and the process of determining and prioritizing effective mass media that would announce the forestry activities in Isparta Forestry Regional Directorate (FRD) to the public was carried out. Thus, it was developed suggestions for the development of mass media in this field. The main purpose of this research is to explore the strengths, weaknesses, opportunities and threats for determining effective mass communication tools in Isparta FRD. The other purposes of this study are to review the current structure regarding mass communication tools, to identify the potentials and the constraints for mass media tools, and to recommend ways to improve the existing structure for them. In this research, it was used the R'WOT technique, which is a hybrid technique connecting Multiple Criteria DecisionMaking Techniques (MCDM) to SWOT (Strengths, Weaknesses, Opportunities and Threats) analysis. This technique is a combined approach utilizing Ranking Technique and Linear Combination Technique when assessing the priorities and the order of importance of SWOT groups and SWOT factors included within each SWOT group. Presented R'WOT Technique is suitable for a variety of different decision making situations. Also, this case study showed the usability of the presented method.

Keywords: Participation, multi criteria decision making, R'WOT, mass media, Isparta, Forestry Regional Directorate (FRD) 


\section{Giriş}

Kurumlar; çalışmalarını ve başarılarını kamuoyuna duyurmak, bilinirliklerini artırmak, toplumun güvenini kazanmak, vermek istedikleri mesajları etkili bir şekilde hedef kitlelere ulaştırmak, görev konularında farkındalık yaratmak için halkla ilişkiler etkinliklerine önem vermektedirler. Halkla ilişkilere yeterince önem vermeyen kurumlarda, hazırlanan basın bültenlerinin gazetelere, dergilere veya televizyonlara gönderilmesi şeklindeki yaklaşım, halkla ilişkiler faaliyetinin etkili bir şekilde yapılmaması sonucunu doğurmaktadır.

"Orman ve orman kaynaklarını korumak, doğaya yakın bir anlayışla geliştirmek, ekosistem bütünlüğü içinde sürdürülebilir ve topluma çok yönlü faydalar sağlayacak şekilde yönetmek" misyonu, "Sürdürülebilir orman yönetimi uygulamalarında öncü kurum olmak" vizyonu olan (OGM, 2016), ülke yüzölçümünün büyük bir kısmında çalışmalar gerçekleştiren, en ücra köşesine kadar örgütlenmiş Orman Genel Müdürlüğü (OGM) de çalışmalarını geniş kitlelere duyurmak ve kamuoyu oluşturmak durumundadir.

Günümüzde en önemli çevre politikası araçlarından biri çevre eğitimidir. Çünkü halkın desteği olmadan doğal kaynakları korumak mümkün değildir. Halk da ancak bildiği, anladığı ve kabul ettiği takdirde koruma süreçlerine destek verecektir. Halkın çevre ve doğal kaynaklar ile ilgili eğitim düzeyinin geliştirilmesi ile çevrenin ve doğal kaynakların sürdürülebilir yönetimi sağlanabilecek ve olumsuz insan etkisi en alt seviyeye indirilecektir (Erol, 2012). Artık kurumlar kamuoyunu olumlu yönde etkilemek, kalıcı izler bırakmak peşindedir. Toplumun beğeni, destek ve güvenini kazanmış kurumlar, amaçlarını yerine getirmek için üstün konuma geçerler. Çünkü bu yolla; halkı aydınlatır, halkın yönetimle olan işlemlerini kolaylaştırır, halkla iş birliği sağlayarak hizmetlerin daha çabuk ve kolay görülmesini sağlar, halkın kuruma ve hizmetlere dair; dilek, istek, tavsiye ve şikâyetlerini dinleyerek yaşanan aksaklıkları gidermeye çalışırlar.

Ormanların korunup geliştirilmesi ve sağladığ faydalar toplumun tamamını ilgilendirmektedir. Halkın katılım sağlamadığ 1 , inanmadığ 1 ve desteklemediği etkinliklerin başarılı olma şansı düşüktür. OGM'nin belirlediği amaçları gerçekleştirmesi ve başarılı olması, bağlantılı olduğu geniş toplum kesimlerinin güven ve desteğini sağlamaya bağl1dır. "Genel Müdürlük faaliyetlerine ait haberlerin sağlıkl kaynaklara dayanılarak ve Bakanlık politikalarl çerçevesinde değerlendirildikten sonra belli bir disiplin içinde medyaya verilmesi, faaliyetlerin doğru şekilde kamuoyuna aktarılması açısın- dan büyük önem taşımaktadır" saptamasını yapan OGM, hedeflediği kitlelere ulaşmak için 27 Orman Bölge Müdürlüğünde "Basın Halkla İlişkiler ve Tanıtım Büroları" kurmuş ve çalışma esaslarını bir tamimle (OGM, 2008) belirlemiştir.

Ulusal Ormancilık Programında (Anonim, 2004) da konu ele alınmış ve genel eylemler kısmının 19. Maddesinde; "Orman teşkilatının halkla ilişkiler, bilinçlendirme ve eğitim konularındaki kurumsal ve eleman kapasitelerinin güçlendirilmesi" şeklinde belirtilmiştir.

Sürdürülebilir Orman Yönetimi Özel İhtisas Komisyonu Raporu, Stratejik Amaç 1.2. Ormanların koruyucu ve çevresel işlevleri ile faydalarının önemi konusunda toplumun bilinçlendirilmesi, sivil ve politik desteğin oluşturulması kapsamında işbirliği gerekli kuruluş olarak TRT, özel TV ve medya kurumları da sayılmıştır. Ayrıca yine bu stratejik amaç altındaki mevzuat düzenlemelerinde; TRT, özel TV kanalları ve diğer kitlesel yayın araçlariyla toplumun bilinçlendirilmesi konusunda 6831 sayılı Kanunda düzenleme yapılması yer almıştır (Anonim, 2014).

Araştırmada; konunun katılımcı bir anlayışla ele alınması suretiyle, demokratik bir toplumun temel bir parçası olan katılımı ı yaklaşımın ele alınan karar verme problemiyle geliştirilmesine ve orman kaynakları yöneticileri tarafından benimsenmesine katkıda bulunmak ve orman idaresinin uygulayacağ1 faaliyetleri ilgi gruplarının tercih, ihtiyaç ve beklentilerini dikkate alarak belirlenmesini sağlamak amaçlanmıştır. Bu doğrultuda çalışmada Isparta Orman Bölge Müdürlüğünde ormanc1lık çalışmalarını kamuoyuna duyuracak etkili kitle iletişim araçlarının belirlenmesi üzerine etkili içsel ve dışsal faktörlerin belirlenmesi, katılımcı bir yaklaşımla ölçülmesi ve önem sırasına konulması konusunda bir karar verme modeli geliştirmek ve bu problem ile ortaya çıkan ÇKKV probleminin çözümünü gösteren örnek uygulama çalışması gerçekleştirmek istenmiştir.

Çalışmada araştırma alanı olarak seçilmiş bulunan Isparta Orman Bölge Müdürlüğü için ormancılık çalışmalarını kamuoyuna duyuracak etkili kitle iletişim araçlarının belirlenmesinde etkili içsel ve dışsal faktörler "SWOT çözümlemeleri" yardımıyla belirlenmiştir. Daha sonra bu faktörler ' $R$ ' $W O T$ tekniği" kullanılarak katılımcı bir yaklaşımla sayısal olarak ölçülmüş ve önem sırasına konulmuştur.

\section{Materyal ve Yöntem}

\subsection{Materyal}

Araştırmada, konu ile ilgili literatür yanında, 
ormancılık çalışmalarını kamuoyuna duyuracak etkili kitle iletişim araçlarının mevcut durumunun ve OGM'nin kurumsal kimliğinin halkla ilişkiler açısından bulunduğu noktanın ortaya konması amacıyla katılımcılara yönelik hazırlanmış "SWOT ve Sıralama Bilgi Formları" kullanılmıştır. Hazırlanan bu formların proje ekibince yüz yüze her bir; Çocuk, Sektör Uzmanı, STK, Orman Köylüsü, Kereste İşletmeleri ve Kamu Kurumu temsilcisi tarafından doldurması sağlanmıştır.

\subsection{Yöntem}

\subsubsection{Hedef kitle}

Çalışmada; Isparta Orman Bölge Müdürlüğü çalışma alanındaki Çocuklar, Sektör Uzmanları, STK temsilcileri, Orman Köylüleri, Kereste İşletmeleri ve Kamu Kurumu (Ormancılık hariç kamu kurumları) temsilcileri hedef kitle olarak alınmıştır. Belirlenen bu toplum katmanlarının görüşleri, temsilcileri aracılığı ile çalışmaya dahil edilmiştir.

UNICEF'in Çocuk Haklarına Dair sözleşmenin 1. Maddesi, "Bu Sözleşme uyarınca çocuğa uygulanabilecek olan kanuna göre daha erken yaşta reşit olma durumu hariç, on sekiz yaşına kadar her insan çocuk sayılır." ifadesini kullanmaktadır (UNICEF, 1989). Proje kapsamında "Çocuklar" şeklinde belirtilen hedef kitle, 18 yaş altını kapsamıştır. Bu kitledeki alt yaş sınırı ise SWOT ve Sıralama Bilgi Formlarını anlayıp bilinçli olarak cevaplayan yaş olarak proje ekibi tarafindan belirlenmiştir. $\mathrm{Bu}$ amaçla ilgili yaş grubunun bulunduğu okullardaki temsilcilerin (sınıf başkanı, eğitsel kol ve kulüp yöneticileri) görüşlerine başvurulmuştur.

\subsection{2. Örnekleme yöntemi}

Çalışmada belirlenen hedef kitleler temsilcileri aracılığı ile örneklenmiş, SWOT ve Sıralama Bilgi Formları yardımıyla özgün veriler elde edilmiştir. $\mathrm{Bu}$ amaçla her bir ilgi grubundan 10'ar temsilci ile çalışılmıştır. Orman köylerinde tesadüfi örnekleme yapılmıştır.

\subsubsection{Veri çözümlemeleri ve değerlendirme yöntemleri}

Isparta Orman Bölge Müdürlüğü çalışma alanındaki Çocuklar, Sektör Uzmanları, STK temsilcileri, Orman Köylüleri, Kereste İşletmeleri ve Kamu Kurumu temsilcilerinin tercihlerini dikkate alarak ormancılık çalışmalarını kamuoyuna duyuracak etkili kitle iletişim araçlarının belirlenmesine yönelik üstünlükleri, zayıflıkları, fırsatları ve tehditleri ortaya koymak amacıyla SWOT çözümlemeleri, Sıralama tekniği ve Doğrusal Kombinasyon tekniğinin bir arada kullanıldığı melez bir teknik olan “R'WOT tekniği” (Yılmaz, 2006; Sönmezler, 2008) kullanılmıştır.

\section{Bulgular}

Öncelikle ormancılık çalışmalarını kamuoyuna duyuracak kitle iletişim araçlarının durumunun değerlendirilmesi amacıyla proje ekibi tarafından, birbirlerinden bağımsız olarak SWOT çözümlemeleri gerçekleştirilmiştir. Sonrasında bir çalışma daha gerçekleştirilerek, proje ekibince ayrı olarak ortaya konulan SWOT çözümlemelerindeki SWOT faktörleri topluca değerlendirilmiştir. $\mathrm{Bu}$ çalışma sonucunda bazı SWOT faktörleri elenmiş, bazıları da aynı faktör altında birleştirilmiştir. Böylece mevcut durumun değerlendirilmesinde dikkate alınacak SWOT grupları ile her bir SWOT grubu dahilindeki SWOT faktörlerine son şekil verilmiştir.

Buna göre ormancılık çalışmalarını kamuoyuna duyuracak kitle iletişim araçlarının durumunu değerlendirmede kullanılacak SWOT çözümlemelerinin "Üstünlükler" grubunda aşağ1daki SWOT faktörlerinin bulunması kararlaştırılmıştır:

1. Orman bölge müdürlüklerinde basın ve halkla ilişkilerden sorumlu bir birimin bulunması

2.OGM bünyesinde Basın ve Halkla İlişkiler Müdürlüğ̈̈’nün bulunması

3. OGM'nin geçmişe dayalı köklü bir kurumsal kimliğe sahip olması

4. Orman işletme müdürlüklerinin (OİM) yapılan çalışmalar hakkında zaman zaman orman köylülerine ve şehirde yaşayanlara faaliyetleri hakkında bilgi vermesi ve onların görüşlerini almasi

5. Orman teşkilatı bünyesinde halkın kullandığı çok sayıdaki korunan alanda hedef kitleye mesaj iletme imkânının bulunması

6. Orman teşkilatının ülkenin en ücra köşesine kadar örgütlenmiş olması

Ormancılık araştırma enstitüsü müdürlüklerinde, halkla ilişkiler ve sosyal ormancılık bölüm başmühendisliğinin bulunması

SWOT çözümlemelerinin "Zayıflıklar" grubunda yer alması kararlaştırılan SWOT faktörleri ise şunlardır:

Halkla ilişkiler konularında hizmet içi eğitimlerin yetersizliği

1. İnsanların doğrudan bilgilendirilmemesinden kaynaklanan kulaktan dolma bilgilerle yanlış kanaatlere varılması 
2.OGM'nin kentte yaşayanlarla kurumsal iletişiminin yetersiz düzeyde kalması

3. OGM'nin yaptığı hizmetlerde alg1 yönetimine yeterince önem vermemesi

4. Orman işletme müdürlüklerinde halkla ilişkiler uzmanının bulunmaması

5. Orman işletme şeflerinin (OİŞ) halkla ilişkiler çalışmalarının sadece kişisel çabalarla sınırlı kalmas1

6. Orman köylerinde halkla ilişkiler çalışmalarını yürütecek, konusunda uzman ve konuları halkın anlayacağı üslupta anlatabilecek elemanların azlığ

SWOT çözümlemelerindeki "Fırsatlar/Olanaklar" grubunda ise aşağıdaki SWOT faktörleri yer almıştır:

1. Gelişen bilişim teknolojisi ile birlikte insanlara ulaşmayı kolaylaştıran medya araçlarının artmasi

2. Halkın bilgilendirilmesi ve bilinçlendirilmesini amaçlayan etkili sivil toplum kuruluşlarının varlığ 1

3. Son yıllarda ülkemizde sesli ve görüntülü yayın organlarının çeşitlenip yaygınlaşması

4. Şehirleşme ile medya kullanım olanaklarının artmas1

5. Toplumda çevre bilincinin artması

6. Toplumda eğitim düzeyi artması

7. Toplumun sosyo-ekonomik olarak gelişmesi

SWOT çözümlemelerine ait "Tehditler/Tehlikeler" grubunu oluşturan SWOT faktörlerinin ise şunlardan oluşmasına karar verilmiştir:

1. Gelişmiş bölgelerde karşılaştırıldığında kırsal bölgede kitle iletişim araçları kullanım kültürünün zayıflığ 1

2.Halkın çevre bilincinin yeterli düzeyde olmamasi

3. Orman içinde veya bitişiğinde yaşayan köylülerin sosyo-ekonomik nedenlerle ormana bağımlılıklarının fazla olması

4. Orman idaresinin en çok ilişkide olduğu orman köylerinde okur-yazar oranının nispeten düşük olmasi

5. Sosyal medyada yaşanan yanlış yönlendirmeler ve bilgi kirliliği

6. Sosyal medyaya yönelik güven eksikliği

7. Toplumun önemli bir kesiminin ormanların giderek azaldığı algısına sahip olması ve bu süreçte de orman teşkilatının payı olduğunu düşünmesi

Bu çalışmada R'WOT tekniği kullanılarak çalışma alanındaki Çocuk temsilcilerine, Sektör Uzmanları temsilcilerine, STK temsilcilerine, Orman Köylüleri temsilcilerine, Kereste İşletmeleri temsilcilerine ve Kamu Kurumları temsilcilerine SWOT grupları ve her bir SWOT grubu içindeki SWOT faktörlerine yönelik karşılaştırmalar yaptırılmıştır. Böylece adı geçen temsilcilerin, ormancılık çalışmalarını kamuoyuna duyuracak kitle iletişim araçlarını değerlendirmede kullanılan SWOT çözümlemelerindeki SWOT grupları ile her bir SWOT grubundaki SWOT faktörlerine ilişkin tercih ve hükümleri ortaya konmuştur. Sonuçta "katılımcı bir yaklaşım" izlenerek ormancılık çalışmalarını kamuoyuna duyuracak kitle iletişim araçları değerlendirilmiştir.

Ormancılık çalışmalarını kamuoyuna duyuracak kitle iletişim araçlarını değerlendirme yönünde, her bir ilgi grubundan 10'ar temsilciye başvurulmuş ve ilgili SWOT grupları ve her bir SWOT grubu içindeki SWOT faktörlerine yönelik tercih ve hüküm belirtmeleri istenmiştir.

Böylece yukarıdaki temsilcilerden elde edilen karşılaştırma bilgileri ve R'WOT tekniği çözüm aşamaları sırasıyla takip edilerek, ormancılık çalışmalarını kamuoyuna duyuracak kitle iletișim araçlarını değerlendirme yönünde SWOT çözümlemeleri ile elde edilen SWOT grupları ve her bir SWOT grubu içindeki SWOT faktörlerine ait nihai öncelik değerleri elde edilmiştir.

Ormancılık çalışmalarını kamuoyuna duyuracak kitle iletişim araçlarının katılımcı bir yaklaşımla değerlendirilmesi amaciyla farklı ilgi grubu temsilcilerine anket çalışması uygulanmıştır. Bu anket çalışmasında, kitle iletişim araçlarının değerlendirilmesine yönelik gerçekleştirilen SWOT çözümlemeleri sonucunda belirlenen SWOT gruplarının (Üstünlükler, Zayıflıklar, Fırsatlar/olanaklar, Tehditler/Tehlikeler) ve her bir SWOT grubu altındaki SWOT faktörlerinin önem durumlarına ilişkin ilgili temsilcilere karşılaştırmalar yaptırılmıştır. Sonrasında bu karşılaştırma işlemleri sonucunda elde edilen veriler, anket uygulanan her bir temsilci itibariyle değerlendirilmiştir. Bu kapsamda her bir temsilciye yönelik olarak R'WOT tekniği kullanılarak, ilgili SWOT grupları ve her bir SWOT grubu dahilindeki SWOT faktörleri için göreceli öncelik değerleri elde edilmiştir. Böylece her bir ilgi grubu itibariyle elde edilen öncelikler ve sonuçta ulaşılan genel öncelikler aşağıda ayrı alt başlıklarda açıklanmaktadır. 


\section{1. İlgi grupları itibariyle öncelikler}

Uygulama alanında anket yapılan temsilciler; Çocuk temsilcileri, Sektör Uzmanları temsilcileri, STK temsilcileri, Orman Köylüleri temsilcileri, Kereste İşletmeleri temsilcileri ve Kamu Kurumları temsilcileri şeklinde gruplandırılmıştır. Sonrasında her katılımcı grubun temsilcilerine ait R'WOT tekniği öncelik sonuçlarının aritmetik ortalaması alınarak, her bir ilgi grubu için SWOT gruplar1 ve her bir SWOT grubundaki SWOT faktörlerinin öncelik değerlerine ulaşılmıştır. Elde edilen sonuçlar, her bir ilgi grubu itibariyle, ayrı alt başlıklar altında aşağıda incelenmiştir.

\subsection{1. Çocuk temsilcilerine ait öncelikler}

Çalışma alanındaki okullarda yer alan (ortaokul ve lise) öğrencilerinden oluşan Çocuk temsilcilerine yönelik R'WOT tekniği çözümleme sonuçları Tablo 1'de verilmiştir.

Buna göre Çocuk temsilcilerine göre en yüksek önceliğe sahip SWOT grubu, 0,25522 öncelik değeri ile "Fırsatlar/Olanaklar" olmuştur. Bunu 0,25330 öncelik değeri ile "Tehditler/Tehlikeler" ve 0,24577 öncelik değeri ile "Zayıflıklar” SWOT grupları izlemiştir. "Üstünlükler” SWOT grubu ise 0,24571 öncelik değeri ile en düşük öncelikli olarak ortaya çıkmıştır.

Çocuk temsilcileri açısından, "Üstünlükler" SWOT grubu dahilinde, en yüksek öncelik değerine sahip SWOT faktörü, 0,04371 öncelik değeri ile "Orman teşkilatının ülkenin en ücra köşesine kadar örgütlenmiş olması" olmuştur. Buna karşın "Zayıflklar" SWOT grubunda yer alan "Orman köylerinde halkla ilişkiler çalışmalarını yürütecek, konusunda uzman ve konuları halkın anlayacă̆ üslupta anlatabilecek elemanların azlığl" SWOT faktörü ise 0,04072 öncelik değeri ile Çocuk temsilcilerince en yüksek önceliği almıştır. Aynı temsilciler için "Firsatlar/Olanaklar" SWOT grubunun öne çıkan SWOT faktörü, 0,04142 öncelik değeri ile "Toplumda eğitim düzeyi artması" faktörüdür. Bu temsilcilere göre "Halkın çevre bilincinin yeterli düzeyde olmaması" SWOT faktörü ise 0,04318 öncelik değeri ile "Tehditler/ Tehlikeler" SWOT grubunun en yüksek öncelikli faktörüdür.

\subsubsection{Sektör uzmanları temsilcilerine ait öncelikler}

Bu çalışmada Sektör Uzmanları temsilcileri olarak kabul edilen Isparta Orman Bölge Müdürlüğü teknik personeli ve medya sektöründeki profesyonellerin SWOT grupları ve her bir SWOT grubu içerisindeki SWOT faktörlerine yönelik yaptıkla- rı karşılaştırmalar esas alınarak, R'WOT tekniği çözümlemeleri ile elde edilen sonuçlar Tablo 2'de sunulmuştur.

Tablo 2'den de görüleceği üzere, Sektör Uzmanları temsilcileri, "Üstünlükler" SWOT grubunu $(0,26261)$, en yüksek öncelikli SWOT grubu olarak görmektedir. Bunu sirasıyla "Tehditler/Tehlikeler" (0,25327), "Firsatlar/Olanaklar" $(0,25068)$ ve " $\mathrm{Za}$ yıflklar" $(0,23345)$ SWOT grupları takip etmektedir.

Sektör Uzmanları temsilcilerine göre, "Üstünlükler" SWOT grubunda en yüksek öncelikli SWOT faktörü "OGM'nin geçmişe dayall köklü bir kurumsal kimliğe sahip olmasl" $(0,04071)$ iken, "Zaylflklar" SWOT grubunda "OGM'nin kentte yaşayanlarla kurumsal iletişiminin yetersiz düzeyde kalması" (0,03492), "Firsatlar/Olanaklar" SWOT grubunda "Gelişen bilişim teknolojisi ile birlikte insanlara ulaşmayı kolaylaştıran medya araçlarının artması" $(0,03919)$ ve "Tehditler/Tehlikeler" SWOT grubunda ise "Sosyal medyaya yönelik güven eksikliği" $(0,03999)$ SWOT faktörleri en yüksek önceliğge sahip olmuştur.

\subsubsection{STK temsilcilerine ait öncelikler}

STK temsilcileri tarafından yapılan karşılaştırmalara göre, R'WOT tekniği kullanılarak elde edilen SWOT grupları ve her bir SWOT grubu içerisindeki SWOT faktörlerine ait öncelik değerleri Tablo 3'te gösterilmektedir.

Tablodaki öncelik değerleri incelendiğinde STK temsilcilerine göre en yüksek önceliğe sahip SWOT grubunun "Tehditler/Tehlikeler" (0,25785) olduğu anlaşılmaktadır. Bu temsilcilere göre bu SWOT grubunu sirasiyla "Zayıflklar" (0,25486), "Üstünlükler" (0,24391) ve "Firsatlar/Olanaklar" $(0,24338)$ SWOT gruplar1 izlemektedir.

“Üstünlükler" SWOT grubu altında "Orman işletme müdürlüklerinin yapılan çalışmalar hakkında zaman zaman orman köylülerine ve şehirde yaşayanlara faaliyetleri hakkında bilgi vermesi ve onların görüşlerini alması" SWOT faktörü 0,03959 öncelik değeri ile STK temsilcileri tarafindan en yüksek öncelikli faktör olarak tercih edilmiştir. Bununla birlikte bu temsilciler için "Orman köylerinde halkla ilişkiler çalışmalarını yürütecek, konusunda uzman ve konuları halkın anlayacă̆l üslupta anlatabilecek elemanların azlığl” (0,04146), "Toplumun sosyo-ekonomik olarak gelişmesi" $(0,03664)$ ve "Sosyal medyaya yönelik güven eksikliği" SWOT faktörleri ise sirasıyla "Zayıflklar", "Firsatlar/Olanaklar" ve "Tehditler/Tehlikeler" SWOT gruplarının en yüksek öncelikli faktörlerini oluşturmuştur. 
Tablo 1. Cocuk temsilcilerine ait " $R$ 'WOT Tekniği" çözümlemeleri

Table 1: "R'WOT Technique" analysis of child representatives

\begin{tabular}{|c|c|c|c|}
\hline $\begin{array}{c}\text { Swot } \\
\text { gruplar1 }\end{array}$ & Öncelik & Swot faktörleri & Öncelik \\
\hline \multirow{7}{*}{ Üstünlükler } & \multirow{7}{*}{0,24571} & $\begin{array}{l}\text { Orman bölge müdürlüklerinde basın ve halkla ilişkilerden sorumlu bir } \\
\text { birimin bulunması }\end{array}$ & 0,03512 \\
\hline & & OGM bünyesinde Basın ve Halkla İlişkiler Müdürlüğ̈̈’nün bulunması & 0,03161 \\
\hline & & OGM'nin geçmişe dayalı köklü bir kurumsal kimliğe sahip olması & 0,03369 \\
\hline & & $\begin{array}{l}\text { Orman işletme müdürlüklerinin yapılan çalışmalar hakkında zaman za- } \\
\text { man orman köylülerine ve şehirde yaşayanlara faaliyetleri hakkında bilgi } \\
\text { vermesi ve onların görüşlerini alması }\end{array}$ & 0,03598 \\
\hline & & $\begin{array}{l}\text { Orman teşkilatı bünyesinde halkın kullandığı çok sayıdaki korunan alan- } \\
\text { da hedef kitleye mesaj iletme imkânının bulunması }\end{array}$ & 0,03637 \\
\hline & & Orman teşkilatının ülkenin en ücra köşesine kadar örgütlenmiş olması & 0,04371 \\
\hline & & $\begin{array}{l}\text { Ormanc1lık araştırma enstitüsü müdürlüklerinde halkla ilişkiler ve sosyal } \\
\text { ormancılık bölüm başmühendisliğinin bulunması }\end{array}$ & 0,02923 \\
\hline \multirow{7}{*}{ Zayıflıklar } & \multirow{7}{*}{0,24577} & Halkla ilişkiler konularında hizmet içi eğitimlerin yetersizliği & 0,03311 \\
\hline & & $\begin{array}{l}\text { İnsanların doğrudan bilgilendirilmemesinden kaynaklanan kulaktan } \\
\text { dolma bilgilerle yanlış kanaatlere varılması }\end{array}$ & 0,03999 \\
\hline & & $\begin{array}{l}\text { OGM'nin kentte yaşayanlarla kurumsal iletişiminin yetersiz düzeyde kal- } \\
\text { ması }\end{array}$ & 0,03539 \\
\hline & & OGM'nin yaptığı hizmetlerde alg1 yönetimine yeterince önem vermemesi & 0,03257 \\
\hline & & Orman işletme müdürlüklerinde halkla ilişkiler uzmanının bulunmaması & 0,02892 \\
\hline & & $\begin{array}{l}\text { Orman işletme şeflerinin halkla ilişkiler çalışmalarının sadece kişisel ça- } \\
\text { balarla sınırlı kalması }\end{array}$ & 0,03507 \\
\hline & & $\begin{array}{l}\text { Orman köylerinde halkla ilişkiler çalışmalarını yürütecek, konusun- } \\
\text { da uzman ve konuları halkın anlayacağı üslupta anlatabilecek ele- } \\
\text { manların azlığı }\end{array}$ & 0,04072 \\
\hline \multirow{7}{*}{$\begin{array}{l}\text { Firsatlar/ } \\
\text { olanaklar }\end{array}$} & \multirow{7}{*}{0,25522} & $\begin{array}{l}\text { Gelişen bilişim teknolojisi ile birlikte insanlara ulaşmayı kolaylaştıran } \\
\text { medya araçlarının artması }\end{array}$ & 0,03747 \\
\hline & & $\begin{array}{l}\text { Halkın bilgilendirilmesi ve bilinçlendirilmesini amaçlayan etkili sivil } \\
\text { toplum kuruluşlarının varlığ }\end{array}$ & 0,03322 \\
\hline & & $\begin{array}{l}\text { Son yıllarda ülkemizde sesli ve görüntülü yayın organlarının çeşitlenip } \\
\text { yaygınlaşması }\end{array}$ & 0,03474 \\
\hline & & Şehirleşme ile medya kullanım olanaklarının artması & 0,03345 \\
\hline & & Toplumda çevre bilincinin artması & 0,03625 \\
\hline & & Toplumda eğitim düzeyi artması & 0,04142 \\
\hline & & Toplumun sosyo-ekonomik olarak gelişmesi & 0,03868 \\
\hline \multirow{7}{*}{$\begin{array}{l}\text { Tehditler/ } \\
\text { tehlikeler }\end{array}$} & \multirow{7}{*}{0,25330} & $\begin{array}{l}\text { Gelişmiş bölgelerde karşılaştırıldığında kırsal bölgede kitle iletiş̧im araç- } \\
\text { ları kullanım kültürünün zayıflığ1 }\end{array}$ & 0,03421 \\
\hline & & Halkın çevre bilincinin yeterli düzeyde olmaması & 0,04318 \\
\hline & & $\begin{array}{l}\text { Orman içinde veya bitişiğinde yaşayan köylülerin sosyo-ekonomik ne- } \\
\text { denlerle ormana bağımlıklarının fazla olması }\end{array}$ & 0,03551 \\
\hline & & $\begin{array}{l}\text { Orman idaresinin en çok ilişkide olduğu orman köylerinde okur-yazar } \\
\text { oranının nispeten düşük olması }\end{array}$ & 0,03661 \\
\hline & & Sosyal medyada yaşanan yanlış yönlendirmeler ve bilgi kirliliği & 0,04001 \\
\hline & & Sosyal medyaya yönelik güven eksikliği & 0,03018 \\
\hline & & $\begin{array}{l}\text { Toplumun önemli bir kesiminin ormanların giderek azaldığ }{ }_{1} \text { algısına sa- } \\
\text { hip olması ve bu süreçte de orman teşkilatının payı olduğunu düşünmesi }\end{array}$ & 0,03360 \\
\hline
\end{tabular}

En yüksek önceliğe sahip SWOT grubu ve her bir SWOT grubu içerisindeki SWOT faktörü, kalın siyah harflerle gösterilmiştir 
Tablo 2. Sektör Uzmanları temsilcilerine ait "R'WOT Tekniği" çözümlemeleri

Table 2: "R'WOT Technique" analysis of sector experts representatives

\begin{tabular}{|c|c|c|c|}
\hline $\begin{array}{l}\text { Swot } \\
\text { gruplar1 }\end{array}$ & Öncelik & Swot faktörleri & Öncelik \\
\hline \multirow{7}{*}{ Üstünlükler } & \multirow{7}{*}{0,26261} & $\begin{array}{l}\text { Orman bölge müdürlüklerinde basın ve halkla ilişkilerden sorumlu bir birimin } \\
\text { bulunması }\end{array}$ & 0,03994 \\
\hline & & OGM bünyesinde Basın ve Halkla İlişkiler Müdürlüğü’nün bulunması & 0,04039 \\
\hline & & OGM'nin geçmişe dayalı köklü bir kurumsal kimliğe sahip olması & 0,04071 \\
\hline & & $\begin{array}{l}\text { Orman işletme müdürlüklerinin yapılan çalışmalar hakkında zaman zaman or- } \\
\text { man köylülerine ve şehirde yaşayanlara faaliyetleri hakkında bilgi vermesi ve } \\
\text { onların görüşlerini alması }\end{array}$ & 0,03861 \\
\hline & & $\begin{array}{l}\text { Orman teşkilatı bünyesinde halkın kullandığı çok sayıdaki korunan alanda he- } \\
\text { def kitleye mesaj iletme imkânının bulunması }\end{array}$ & 0,03279 \\
\hline & & Orman teşkilatının ülkenin en ücra köşesine kadar örgütlenmiş olması & 0,03946 \\
\hline & & $\begin{array}{l}\text { Ormancılık araştırma enstitüsü müdürlüklerinde halkla ilişsiler ve sosyal or- } \\
\text { mancılık bölüm başmühendisliğinin bulunması }\end{array}$ & 0,03072 \\
\hline \multirow{7}{*}{ Zayıflıklar } & \multirow{7}{*}{0,23345} & Halkla ilişkiler konularında hizmet içi eğitimlerin yetersizliği & 0,03337 \\
\hline & & $\begin{array}{l}\text { İnsanların doğrudan bilgilendirilmemesinden kaynaklanan kulaktan dolma } \\
\text { bilgilerle yanlış kanaatlere varılması }\end{array}$ & 0,03341 \\
\hline & & OGM'nin kentte yaşayanlarla kurumsal iletişiminin yetersiz düzeyde kalması & 0,03492 \\
\hline & & OGM'nin yaptı̆̆ 1 hizmetlerde alg1 yönetimine yeterince önem vermemesi & 0,03491 \\
\hline & & Orman işletme müdürlüklerinde halkla ilişkiler uzmanının bulunmaması & 0,03046 \\
\hline & & $\begin{array}{l}\text { Orman işletme şeflerinin halkla ilişkiler çalışmalarının sadece kişisel çabalarla } \\
\text { sınırlı kalması }\end{array}$ & 0,03485 \\
\hline & & $\begin{array}{l}\text { Orman köylerinde halkla ilişkiler çalışmalarını yürütecek, konusunda uzman } \\
\text { ve konuları halkın anlayacağı üslupta anlatabilecek elemanların azlığı }\end{array}$ & 0,03152 \\
\hline \multirow{7}{*}{$\begin{array}{l}\text { Firsatlar/ } \\
\text { olanaklar }\end{array}$} & \multirow{7}{*}{0,25068} & $\begin{array}{l}\text { Gelişen bilişim teknolojisi ile birlikte insanlara ulaşmayı kolaylaştıran } \\
\text { medya araçlarının artması }\end{array}$ & $\mathbf{0 , 0 3 9 1 9}$ \\
\hline & & $\begin{array}{l}\text { Halkın bilgilendirilmesi ve bilinçlendirilmesini amaçlayan etkili sivil toplum } \\
\text { kuruluşlarının varlığı }\end{array}$ & 0,03292 \\
\hline & & $\begin{array}{l}\text { Son yıllarda ülkemizde sesli ve görüntülü yayın organlarının çeşitlenip yay- } \\
\text { gınlaşması }\end{array}$ & 0,03785 \\
\hline & & Şehirleşme ile medya kullanım olanaklarının artması & 0,03504 \\
\hline & & Toplumda çevre bilincinin artması & 0,03901 \\
\hline & & Toplumda eğitim düzeyi artması & 0,03489 \\
\hline & & Toplumun sosyo-ekonomik olarak gelişmesi & 0,03177 \\
\hline \multirow{7}{*}{$\begin{array}{l}\text { Tehditler/ } \\
\text { tehlikeler }\end{array}$} & \multirow{7}{*}{0,25327} & $\begin{array}{l}\text { Gelişmiş bölgelerde karşılaştırıldığında kırsal bölgede kitle iletişim araçları } \\
\text { kullanım kültürünün zayıflığ1 }\end{array}$ & 0,03460 \\
\hline & & Halkın çevre bilincinin yeterli düzeyde olmaması & 0,03632 \\
\hline & & $\begin{array}{l}\text { Orman içinde veya bitişiğinde yaşayan köylülerin sosyo-ekonomik nedenlerle } \\
\text { ormana bağımlılıklarının fazla olması }\end{array}$ & 0,03654 \\
\hline & & $\begin{array}{l}\text { Orman idaresinin en çok ilişkide olduğu orman köylerinde okur-yazar oranının } \\
\text { nispeten düşük olması }\end{array}$ & 0,03497 \\
\hline & & Sosyal medyada yaşanan yanlış yönlendirmeler ve bilgi kirliliği & 0,03757 \\
\hline & & Sosyal medyaya yönelik güven eksikliği & 0,03999 \\
\hline & & $\begin{array}{l}\text { Toplumun önemli bir kesiminin ormanların giderek azaldığı algısına sahip ol- } \\
\text { ması ve bu süreçte de orman teşkilatının payı olduğunu düşünmesi }\end{array}$ & 0,03327 \\
\hline
\end{tabular}


Tablo 3. STK temsilcilerine ait " $R$ 'WOT Tekniğ $i$ ” çözümlemeleri

Table 3: "R'WOT Technique" analysis of NGOs representatives

\begin{tabular}{|c|c|c|c|}
\hline $\begin{array}{l}\text { Swot } \\
\text { gruplar1 }\end{array}$ & Öncelik & Swot faktörleri & Öncelik \\
\hline \multirow{7}{*}{ Üstünlükler } & \multirow{7}{*}{0,24391} & $\begin{array}{l}\text { Orman bölge müdürlüklerinde basın ve halkla ilişkilerden sorumlu bir bi- } \\
\text { rimin bulunması }\end{array}$ & 0,03334 \\
\hline & & OGM bünyesinde Basın ve Halkla İlişkiler Müdürlüğü’nün bulunması & 0,03199 \\
\hline & & OGM’nin geçmişe dayalı köklü bir kurumsal kimliğe sahip olması & 0,03716 \\
\hline & & $\begin{array}{l}\text { Orman işletme müdürlüklerinin yapılan çalışmalar hakkında zaman } \\
\text { zaman orman köylülerine ve şehirde yaşayanlara faaliyetleri hakkında } \\
\text { bilgi vermesi ve onların görüşlerini alması }\end{array}$ & $\mathbf{0 , 0 3 9 5 9}$ \\
\hline & & $\begin{array}{l}\text { Orman teşkilatı bünyesinde halkın kullandığı çok sayıdaki korunan alanda } \\
\text { hedef kitleye mesaj iletme imkânının bulunması }\end{array}$ & 0,03495 \\
\hline & & Orman teşkilatının ülkenin en ücra köşesine kadar örgütlenmiş olması & 0,03874 \\
\hline & & $\begin{array}{l}\text { Ormancılık araştırma enstitüsü müdürlüklerinde halkla ilişkiler ve sosyal } \\
\text { ormancılık bölüm başmühendisliğinin bulunması }\end{array}$ & 0,02813 \\
\hline \multirow{7}{*}{ Zayıflıklar } & \multirow{7}{*}{0,25486} & Halkla ilişkiler konularında hizmet içi eğitimlerin yetersizliği & 0,03378 \\
\hline & & $\begin{array}{l}\text { İnsanların doğrudan bilgilendirilmemesinden kaynaklanan kulaktan dolma } \\
\text { bilgilerle yanlış kanaatlere varılması }\end{array}$ & 0,03744 \\
\hline & & $\begin{array}{l}\text { OGM'nin kentte yaşayanlarla kurumsal iletişiminin yetersiz düzeyde kal- } \\
\text { mas1 }\end{array}$ & 0,03704 \\
\hline & & OGM'nin yaptığı hizmetlerde alg1 yönetimine yeterince önem vermemesi & 0,03042 \\
\hline & & Orman işletme müdürlüklerinde halkla ilişkiler uzmanının bulunmaması & 0,03623 \\
\hline & & $\begin{array}{l}\text { Orman işletme şeflerinin halkla ilişkiler çalışmalarının sadece kişisel ça- } \\
\text { balarla sınırlı kalması }\end{array}$ & 0,03849 \\
\hline & & $\begin{array}{l}\text { Orman köylerinde halkla ilişkiler çalışmalarını yürütecek, konusunda } \\
\text { uzman ve konuları halkın anlayacağı üslupta anlatabilecek elemanla- } \\
\text { rın azlığı }\end{array}$ & $\mathbf{0 , 0 4 1 4 6}$ \\
\hline \multirow{7}{*}{$\begin{array}{l}\text { Firsatlar/ } \\
\text { olanaklar }\end{array}$} & \multirow{7}{*}{0,24338} & $\begin{array}{l}\text { Gelişen bilişim teknolojisi ile birlikte insanlara ulaşmayı kolaylaştıran } \\
\text { medya araçlarının artması }\end{array}$ & 0,03505 \\
\hline & & $\begin{array}{l}\text { Halkın bilgilendirilmesi ve bilinçlendirilmesini amaçlayan etkili sivil top- } \\
\text { lum kuruluşlarının varlığı }\end{array}$ & 0,03122 \\
\hline & & $\begin{array}{l}\text { Son yıllarda ülkemizde sesli ve görüntülü yayın organlarının çeşitlenip } \\
\text { yaygınlaşması }\end{array}$ & 0,03520 \\
\hline & & Şehirleşme ile medya kullanım olanaklarının artması & 0,03423 \\
\hline & & Toplumda çevre bilincinin artması & 0,03571 \\
\hline & & Toplumda eğitim düzeyi artması & 0,03532 \\
\hline & & Toplumun sosyo-ekonomik olarak gelişmesi & 0,03664 \\
\hline \multirow{7}{*}{$\begin{array}{l}\text { Tehditler/ } \\
\text { tehlikeler }\end{array}$} & \multirow{7}{*}{0,25785} & $\begin{array}{l}\text { Gelişmiş bölgelerde karşılaştırıldığında kırsal bölgede kitle iletişim araçla- } \\
\text { r1 kullanım kültürünün zayıflığı }\end{array}$ & 0,03409 \\
\hline & & Halkın çevre bilincinin yeterli düzeyde olmaması & 0,03891 \\
\hline & & $\begin{array}{l}\text { Orman içinde veya bitişiğinde yaşayan köylülerin sosyo-ekonomik neden- } \\
\text { lerle ormana bağımlılıklarının fazla olması }\end{array}$ & 0,03609 \\
\hline & & $\begin{array}{l}\text { Orman idaresinin en çok ilişkide olduğu orman köylerinde okur-yazar ora- } \\
\text { nının nispeten düşük olması }\end{array}$ & 0,03499 \\
\hline & & Sosyal medyada yaşanan yanlış yönlendirmeler ve bilgi kirliliği & 0,03974 \\
\hline & & Sosyal medyaya yönelik güven eksikliği & $\mathbf{0 , 0 3 9 9 8}$ \\
\hline & & $\begin{array}{l}\text { Toplumun önemli bir kesiminin ormanların giderek azaldı̆̆ı algısına sahip } \\
\text { olması ve bu süreçte de orman teşkilatının payı olduğunu düşünmesi }\end{array}$ & 0,03406 \\
\hline
\end{tabular}




\subsubsection{Orman köylüleri temsilcilerine ait öncelikler}

$\mathrm{Bu}$ çalışmanın Orman Köylüleri temsilcilerinin SWOT gruplarına ve her bir SWOT grubundaki SWOT faktörlerine yönelik karşılaştırmalarına dayalı olarak R'WOT tekniği çözümlemeleri ile elde edilen öncelik değerleri Tablo 4'te sunulmaktadır.

Bu öncelik değerlerine göre Orman Köylüleri temsilcileri en yüksek öncelikli SWOT grubu olarak "Zayıflklar" grubunu (0,25476) düşünmekte, bunu sirasiyla "Tehditler/Tehlikeler" (0,25158), "Üstünlükler" $(0,24738)$ ve "Firsatlar/Olanaklar" $(0,24628)$ SWOT grupları izlemektedir.

Aynı temsilciler için "Üstünlükler” SWOT grubundaki en yüksek öncelikli SWOT faktörü, 0,03983 öncelik değeri ile "OGM'nin geçmişe dayalı köklü bir kurumsal kimliğe sahip olması" iken "Zayıflıklar" SWOT grubunda yer alan "Orman köylerinde halkla ilişkiler çalışmalarını yürütecek, konusunda uzman ve konuları halkın anlayacağı üslupta anlatabilecek elemanların azlığı" SWOT faktörü 0,04105 öncelik değeri ile en yüksek öncelikli faktör olarak kabul edilmektedir. Buna karşın adı geçen temsilciler tarafından "Fırsatlar/ Olanaklar" kapsamındaki "Gelișen bilișim teknolojisi ile birlikte insanlara ulaşmayı kolaylaştıran medya araçlarının artması" SWOT faktörü 0,03812 öncelik değeriyle ve "Tehditler/Tehlikeler" SWOT grubunda yer alan "Orman idaresinin en çok ilişkide olduğu orman köylerinde okur-yazar oranının nispeten düşük olması" SWOT faktörü ise 0,04000 öncelik değeriyle en yüksek öncelikli faktörler olarak ifade edilmiştir.

\subsubsection{Kereste İşletmeleri temsilcilerine ait öncelikler}

Kereste İşletmeleri temsilcilerinin SWOT grupları ve her bir SWOT grubundaki SWOT faktörleri için yaptıkları karşılaştırmalara göre, R'WOT tekniği kullanılarak elde edilen öncelik değerleri Tablo 5'te verilmektedir.

Çizelgede verilen öncelik değerleri dikkate alındığında, Kereste İşletmeleri temsilcileri için en yüksek öncelikli SWOT grubu "Tehditler/Tehlikeler" $(0,26130)$ iken, bunu sirasıyla "Zayıflıklar" $(0,26063)$, “Üstünlükler" $(0,23987)$ ve "Firsatlar/ Olanaklar" $(0,23820)$ SWOT grupları izlemektedir.

Kereste İşletmeleri temsilcileri "Üstünlükler" SWOT grubu içerisinde en yüksek önceliği "Orman teşkilatının ülkenin en ücra köşesine kadar örgütlenmiş olması" $(0,04286)$ SWOT faktörüne vermekte iken, "Zayıflıklar" SWOT grubunda
"İnsanların doğrudan bilgilendirilmemesinden kaynaklanan kulaktan dolma bilgilerle yanlış kanaatlere varılması" $(0,03270)$, "Firsatlar/Olanaklar" SWOT grubunda "Toplumda çevre bilincinin artmas1" $(0,03977)$ ve nihayet "Tehditler/Tehlikeler" SWOT grubunda ise "Halkın çevre bilincinin yeterli düzeyde olmaması" $(0,04086)$ SWOT faktörlerine en yüksek önceliği uygun bulmuştur.

\subsubsection{Kamu kurumları temsilcilerine ait öncelikler}

Kamu Kurumları temsilcilerinin SWOT grupları ve her bir SWOT grubundaki SWOT faktörlerine yönelik yaptıkları karşılaştırmalar esas alınarak, R'WOT tekniği ile hesaplanan öncelik değerleri Tablo 6'da gösterilmektedir.

Çizelgedeki öncelik değerlerine göre, Kamu Kurumları temsilcileri SWOT grupları içerisinde en yüksek önceliği "Zayıflıklar" $(0,26700)$ grubuna vermektedir. Bunu sirasıyla "Üstünlükler" $(0,25052)$, "Firsatlar/Olanaklar" $(0,24214)$ ve "Tehditler/Tehlikeler" $(0,24033)$ SWOT grupları takip etmektedir.

Öte yandan Kamu Kurumları temsilcileri, "Üstünlükler" SWOT grubu kapsamında "Orman işletme müdürlüklerinin yapılan çalışmalar hakkında zaman zaman orman köylülerine ve şehirde yaşayanlara faaliyetleri hakkında bilgi vermesi ve onların görüşlerini alması" $(0,04045)$ SWOT faktörünü en yüksek öncelikli faktör olarak görmektedir. Buna karşın Kamu Kurumları temsilcileri için "Zayıflıklar” SWOT grubunun en yüksek öncelikli SWOT faktörü "İnsanların doğrudan bilgilendirilmemesinden kaynaklanan kulaktan dolma bilgilerle yanlış kanaatlere varılması" $(0,04372)$ iken, "Fırsatlar/Olanaklar" SWOT grubunda "Toplumda çevre bilincinin artması" $(0,03687)$ ve "Tehditler/ Tehlikeler" SWOT grubunda ise "Sosyal medyada yaşanan yanlış yönlendirmeler ve bilgi kirliliği" $(0,0,03971)$ SWOT faktörleri en yüksek öncelikli olarak tercih edilmektedir.

\subsection{Genel öncelikler}

Bu çalışmada, Isparta Orman Bölge Müdürlüğü çalışma alanındaki Çocuk temsilcileri, Sektör Uzmanları temsilcileri, STK temsilcileri, Orman Köylüleri temsilcileri, Kereste İşletmeleri temsilcileri ve Kamu Kurumları temsilcilerinden oluşan toplam 60 temsilciye, SWOT grupları ve her bir SWOT grubu içerisindeki SWOT faktörlerine yönelik karşılaştırmalar yaptırılmıştır. Bu şekilde elde edilen karşılaştırma verileri, R'WOT tekniği çözümlemelerinin girdilerini oluşturmuştur. Böylece R'WOT tekniği yardımıyla, her bir temsilci 
Tablo 4. Orman köylüleri temsilcilerine ait " $R$ 'WOT Tekniği i" çözümlemeleri

Table 4: "R'WOT Technique" analysis of forest villagers representatives

\begin{tabular}{|c|c|c|c|}
\hline $\begin{array}{c}\text { Swot } \\
\text { gruplar1 }\end{array}$ & Öncelik & Swot faktörleri & Öncelik \\
\hline \multirow{7}{*}{ Üstünlükler } & \multirow{7}{*}{0,24738} & $\begin{array}{l}\text { Orman bölge müdürlüklerinde basın ve halkla ilişkilerden sorumlu bir } \\
\text { birimin bulunması }\end{array}$ & 0,03505 \\
\hline & & OGM bünyesinde Basın ve Halkla İlişsiler Müdürlüğ̈̈nün bulunması & 0,03305 \\
\hline & & OGM'nin geçmişe dayalı köklü bir kurumsal kimliğe sahip olması & 0,03983 \\
\hline & & $\begin{array}{l}\text { Orman işletme müdürlüklerinin yapılan çalışmalar hakkında zaman za- } \\
\text { man orman köylülerine ve şehirde yaşayanlara faaliyetleri hakkında bilgi } \\
\text { vermesi ve onların görüşlerini alması }\end{array}$ & 0,04083 \\
\hline & & $\begin{array}{l}\text { Orman teşkilatı bünyesinde halkın kullandığı çok sayıdaki korunan alan- } \\
\text { da hedef kitleye mesaj iletme imkânının bulunması }\end{array}$ & 0,03120 \\
\hline & & Orman teşkilatının ülkenin en ücra köşesine kadar örgütlenmiş olması & 0,03806 \\
\hline & & $\begin{array}{l}\text { Ormancılık araştırma enstitüsü müdürlüklerinde halkla ilişkiler ve sos- } \\
\text { yal ormancılık bölüm başmühendisliğinin bulunması }\end{array}$ & 0,02936 \\
\hline \multirow{7}{*}{ Zayıflıklar } & \multirow{7}{*}{0,25476} & Halkla ilişkiler konularında hizmet içi eğitimlerin yetersizliği & 0,03451 \\
\hline & & $\begin{array}{l}\text { İnsanların doğrudan bilgilendirilmemesinden kaynaklanan kulaktan } \\
\text { dolma bilgilerle yanlış kanaatlere varılması }\end{array}$ & 0,04015 \\
\hline & & $\begin{array}{l}\text { OGM'nin kentte yaşayanlarla kurumsal iletişiminin yetersiz düzeyde } \\
\text { kalması }\end{array}$ & 0,03048 \\
\hline & & OGM'nin yaptığı hizmetlerde algı yönetimine yeterince önem vermemesi & 0,03276 \\
\hline & & Orman işletme müdürlüklerinde halkla ilişkiler uzmanının bulunmaması & 0,03778 \\
\hline & & $\begin{array}{l}\text { Orman işletme şeflerinin halkla ilişkiler çalışmalarının sadece kişisel ça- } \\
\text { balarla sınırlı kalması }\end{array}$ & 0,03803 \\
\hline & & $\begin{array}{l}\text { Orman köylerinde halkla ilişkiler çalışmalarını yürütecek, konusun- } \\
\text { da uzman ve konuları halkın anlayacağı üslupta anlatabilecek ele- } \\
\text { manların azlığı }\end{array}$ & 0,04105 \\
\hline \multirow{7}{*}{$\begin{array}{l}\text { Firsatlar/ } \\
\text { olanaklar }\end{array}$} & \multirow{7}{*}{0,24628} & $\begin{array}{l}\text { Gelişen bilişim teknolojisi ile birlikte insanlara ulaşmayı kolaylaştı- } \\
\text { ran medya araçlarının artması }\end{array}$ & $\mathbf{0 , 0 3 8 1 2}$ \\
\hline & & $\begin{array}{l}\text { Halkın bilgilendirilmesi ve bilinçlendirilmesini amaçlayan etkili sivil } \\
\text { toplum kuruluşlarının varlığı }\end{array}$ & 0,02878 \\
\hline & & $\begin{array}{l}\text { Son yıllarda ülkemizde sesli ve görüntülü yayın organlarının çeşitlenip } \\
\text { yaygınlaşması }\end{array}$ & 0,03785 \\
\hline & & Şehirleşme ile medya kullanım olanaklarının artması & 0,03193 \\
\hline & & Toplumda çevre bilincinin artması & 0,03606 \\
\hline & & Toplumda eğitim düzeyi artması & 0,03808 \\
\hline & & Toplumun sosyo-ekonomik olarak gelişmesi & 0,03545 \\
\hline \multirow{7}{*}{$\begin{array}{l}\text { Tehditler/ } \\
\text { tehlikeler }\end{array}$} & \multirow{7}{*}{0,25158} & $\begin{array}{l}\text { Gelişmiş bölgelerde karşılaştırıldığında kırsal bölgede kitle iletiş̧im araç- } \\
\text { ları kullanım kültürünün zayıflığ }\end{array}$ & 0,03296 \\
\hline & & Halkın çevre bilincinin yeterli düzeyde olmaması & 0,03772 \\
\hline & & $\begin{array}{l}\text { Orman içinde veya bitişiğinde yaşayan köylülerin sosyo-ekonomik ne- } \\
\text { denlerle ormana bağımlılıklarının fazla olması }\end{array}$ & 0,03231 \\
\hline & & $\begin{array}{l}\text { Orman idaresinin en çok ilişkide olduğu orman köylerinde okur-ya- } \\
\text { zar oranının nispeten düşük olması }\end{array}$ & 0,04000 \\
\hline & & Sosyal medyada yaşanan yanlış yönlendirmeler ve bilgi kirliliği & 0,03650 \\
\hline & & Sosyal medyaya yönelik güven eksikliği & 0,03619 \\
\hline & & $\begin{array}{l}\text { Toplumun önemli bir kesiminin ormanların giderek azaldığ algısına sa- } \\
\text { hip olması ve bu süreçte de orman teşkilatının payı olduğunu düşünmesi }\end{array}$ & 0,03590 \\
\hline
\end{tabular}


Tablo 5. Kereste işletmeleri temsilcilerine Ait “ $R$ 'WOT Tekniği” çözümlemeleri

Table 5: "R'WOT Technique" analysis of timber business representatives

\begin{tabular}{|c|c|c|c|}
\hline $\begin{array}{c}\text { Swot } \\
\text { gruplar1 }\end{array}$ & Öncelik & Swot faktörleri & Öncelik \\
\hline \multirow{7}{*}{ Üstünlükler } & \multirow{7}{*}{0,23987} & $\begin{array}{l}\text { Orman bölge müdürlüklerinde basın ve halkla ilişkilerden sorumlu bir } \\
\text { birimin bulunması }\end{array}$ & 0,03704 \\
\hline & & OGM bünyesinde Basın ve Halkla İlişkiler Müdürlüğü’nün bulunması & 0,03478 \\
\hline & & OGM'nin geçmişe dayalı köklü bir kurumsal kimliğe sahip olması & 0,03783 \\
\hline & & $\begin{array}{l}\text { Orman işletme müdürlüklerinin yapılan çalışmalar hakkında zaman za- } \\
\text { man orman köylülerine ve şehirde yaşayanlara faaliyetleri hakkında bilgi } \\
\text { vermesi ve onların görüşlerini alması }\end{array}$ & 0,03867 \\
\hline & & $\begin{array}{l}\text { Orman teşkilatı bünyesinde halkın kullandı̆̆ı çok sayıdaki korunan alan- } \\
\text { da hedef kitleye mesaj iletme imkânının bulunması }\end{array}$ & 0,03652 \\
\hline & & Orman teşkilatının ülkenin en ücra köşesine kadar örgütlenmiş olması & 0,04286 \\
\hline & & $\begin{array}{l}\text { Ormancılık araştırma enstitüsü müdürlüklerinde halkla ilişkiler ve sosyal } \\
\text { ormancılık bölüm başmühendisliğinin bulunması }\end{array}$ & 0,03699 \\
\hline \multirow{7}{*}{ Zayıflıklar } & \multirow{7}{*}{0,26063} & Halkla ilişkiler konularında hizmet içi eğitimlerin yetersizliği & 0,02472 \\
\hline & & $\begin{array}{l}\text { İnsanların doğrudan bilgilendirilmemesinden kaynaklanan kulaktan } \\
\text { dolma bilgilerle yanlış kanaatlere varılması }\end{array}$ & $\mathbf{0 , 0 3 2 7 0}$ \\
\hline & & $\begin{array}{l}\text { OGM'nin kentte yaşayanlarla kurumsal iletişiminin yetersiz düzeyde } \\
\text { kalması }\end{array}$ & 0,03039 \\
\hline & & OGM'nin yaptığı hizmetlerde alg1 yönetimine yeterince önem vermemesi & 0,02994 \\
\hline & & Orman işletme müdürlüklerinde halkla ilişkiler uzmanının bulunmaması & 0,02686 \\
\hline & & $\begin{array}{l}\text { Orman işletme şeflerinin halkla ilişkiler çalışmalarının sadece kişisel ça- } \\
\text { balarla sınırlı kalması }\end{array}$ & 0,02970 \\
\hline & & $\begin{array}{l}\text { Orman köylerinde halkla ilişkiler çalışmalarını yürütecek, konusunda } \\
\text { uzman ve konuları halkın anlayacağ } 1 \text { üslupta anlatabilecek elemanların } \\
\text { azlığ1 }\end{array}$ & 0,03157 \\
\hline \multirow{7}{*}{$\begin{array}{l}\text { Firsatlar/ } \\
\text { olanaklar }\end{array}$} & \multirow{7}{*}{0,23820} & $\begin{array}{l}\text { Gelişen bilişim teknolojisi ile birlikte insanlara ulaşmayı kolaylaştıran } \\
\text { medya araçlarının artması }\end{array}$ & 0,03957 \\
\hline & & $\begin{array}{l}\text { Halkın bilgilendirilmesi ve bilinçlendirilmesini amaçlayan etkili sivil } \\
\text { toplum kuruluşlarının varlığ } 1\end{array}$ & 0,03486 \\
\hline & & $\begin{array}{l}\text { Son yıllarda ülkemizde sesli ve görüntülü yayın organlarının çeşitlenip } \\
\text { yaygınlaşması }\end{array}$ & 0,03792 \\
\hline & & Şehirleşme ile medya kullanım olanaklarının artması & 0,03838 \\
\hline & & Toplumda çevre bilincinin artması & $\mathbf{0 , 0 3 9 7 7}$ \\
\hline & & Toplumda eğitim düzeyi artması & 0,03911 \\
\hline & & Toplumun sosyo-ekonomik olarak gelişmesi & 0,03510 \\
\hline \multirow{7}{*}{$\begin{array}{l}\text { Tehditler/ } \\
\text { tehlikeler }\end{array}$} & \multirow{7}{*}{0,26130} & $\begin{array}{l}\text { Gelişmiş bölgelerde karşılaştırıldığında kırsal bölgede kitle iletişim araç- } \\
\text { ları kullanım kültürünün zayıflığ1 }\end{array}$ & 0,03732 \\
\hline & & Halkın çevre bilincinin yeterli düzeyde olmaması & 0,04086 \\
\hline & & $\begin{array}{l}\text { Orman içinde veya bitişiğinde yaşayan köylülerin sosyo-ekonomik ne- } \\
\text { denlerle ormana bağımlılıklarının fazla olması }\end{array}$ & 0,03274 \\
\hline & & $\begin{array}{l}\text { Orman idaresinin en çok ilişkide olduğu orman köylerinde okur-yazar } \\
\text { oranının nispeten düşük olması }\end{array}$ & 0,03565 \\
\hline & & Sosyal medyada yaşanan yanlış yönlendirmeler ve bilgi kirliliği & 0,03903 \\
\hline & & Sosyal medyaya yönelik güven eksikliği & 0,04011 \\
\hline & & $\begin{array}{l}\text { Toplumun önemli bir kesiminin ormanların giderek azaldığ } 1 \text { algısına sa- } \\
\text { hip olması ve bu süreçte de orman teșkilatının payı olduğunu düșünmesi }\end{array}$ & 0,03899 \\
\hline
\end{tabular}


Tablo 6. Kamu kurumları temsilcilerine ait " $R$ 'WOT Tekniğì" çözümlemeleri

Table 6: "R'WOT Technique" analyzes of public institutions representatives

\begin{tabular}{|c|c|c|c|}
\hline $\begin{array}{l}\text { Swot } \\
\text { gruplar1 }\end{array}$ & Öncelik & Swot faktörleri & Öncelik \\
\hline \multirow{7}{*}{ Üstünlükler } & \multirow{7}{*}{0,25052} & $\begin{array}{l}\text { Orman bölge müdürlüklerinde basın ve halkla ilişkilerden sorumlu bir biri- } \\
\text { min bulunması }\end{array}$ & 0,04041 \\
\hline & & OGM bünyesinde Basın ve Halkla İlişkiler Müdürlüğü’nün bulunması & 0,03636 \\
\hline & & OGM'nin geçmişe dayalı köklü bir kurumsal kimliğe sahip olması & 0,02831 \\
\hline & & $\begin{array}{l}\text { Orman işletme müdürlüklerinin yapılan çalışmalar hakkında zaman } \\
\text { zaman orman köylülerine ve şehirde yaşayanlara faaliyetleri hakkında } \\
\text { bilgi vermesi ve onların görüşlerini alması }\end{array}$ & 0,04045 \\
\hline & & $\begin{array}{l}\text { Orman teşkilatı bünyesinde halkın kullandığı çok sayıdaki korunan alanda } \\
\text { hedef kitleye mesaj iletme imkânının bulunması }\end{array}$ & 0,03750 \\
\hline & & Orman teşkilatının ülkenin en ücra köşesine kadar örgütlenmiş olması & 0,03766 \\
\hline & & $\begin{array}{l}\text { Ormancılık araştırma enstitüsü müdürlüklerinde halkla ilişkiler ve sosyal } \\
\text { ormancılık bölüm başmühendisliğinin bulunması }\end{array}$ & 0,02984 \\
\hline \multirow{7}{*}{ Zayıflıklar } & \multirow{7}{*}{0,26700} & Halkla ilişkiler konularında hizmet içi eğitimlerin yetersizliği & 0,03478 \\
\hline & & $\begin{array}{l}\text { İnsanların doğrudan bilgilendirilmemesinden kaynaklanan kulaktan } \\
\text { dolma bilgilerle yanlış kanaatlere varılması }\end{array}$ & $\mathbf{0 , 0 4 3 7 2}$ \\
\hline & & $\begin{array}{l}\text { OGM'nin kentte yaşayanlarla kurumsal iletişiminin yetersiz düzeyde kal- } \\
\text { ması }\end{array}$ & 0,03818 \\
\hline & & OGM'nin yaptığı hizmetlerde alg1 yönetimine yeterince önem vermemesi & 0,03810 \\
\hline & & Orman işletme müdürlüklerinde halkla ilişkiler uzmanının bulunmaması & 0,03601 \\
\hline & & $\begin{array}{l}\text { Orman işletme şeflerinin halkla ilişkiler çalışmalarının sadece kişisel çaba- } \\
\text { larla sınırlı kalması }\end{array}$ & 0,03938 \\
\hline & & $\begin{array}{l}\text { Orman köylerinde halkla ilişkiler çalışmalarını yürütecek, konusunda uz- } \\
\text { man ve konuları halkın anlayacağı üslupta anlatabilecek elemanların azlığı }\end{array}$ & 0,03683 \\
\hline \multirow{7}{*}{$\begin{array}{l}\text { Firsatlar/ } \\
\text { olanaklar }\end{array}$} & \multirow{7}{*}{0,24214} & $\begin{array}{l}\text { Gelişen bilişim teknolojisi ile birlikte insanlara ulaşmayı kolaylaştıran med- } \\
\text { ya araçlarının artması }\end{array}$ & 0,03671 \\
\hline & & $\begin{array}{l}\text { Halkın bilgilendirilmesi ve bilinçlendirilmesini amaçlayan etkili sivil top- } \\
\text { lum kuruluşlarının varlığı }\end{array}$ & 0,03112 \\
\hline & & $\begin{array}{l}\text { Son yıllarda ülkemizde sesli ve görüntülü yayın organlarının çeşitlenip yay- } \\
\text { gınlaşması }\end{array}$ & 0,03502 \\
\hline & & Şehirleşme ile medya kullanım olanaklarının artması & 0,03312 \\
\hline & & Toplumda çevre bilincinin artması & $\mathbf{0 , 0 3 6 8 7}$ \\
\hline & & Toplumda eğitim düzeyi artması & 0,03582 \\
\hline & & Toplumun sosyo-ekonomik olarak gelişmesi & 0,03348 \\
\hline \multirow{7}{*}{$\begin{array}{l}\text { Tehditler/ } \\
\text { tehlikeler }\end{array}$} & \multirow{7}{*}{0,24033} & $\begin{array}{l}\text { Gelişmiş bölgelerde karşılaştırıldığında kırsal bölgede kitle iletişim araçları } \\
\text { kullanım kültürünün zayıflığ1 }\end{array}$ & 0,02816 \\
\hline & & Halkın çevre bilincinin yeterli düzeyde olmaması & 0,03402 \\
\hline & & $\begin{array}{l}\text { Orman içinde veya bitişiğinde yaşayan köylülerin sosyo-ekonomik neden- } \\
\text { lerle ormana bağımlılıklarının fazla olması }\end{array}$ & 0,03519 \\
\hline & & $\begin{array}{l}\text { Orman idaresinin en çok ilişkide olduğu orman köylerinde okur-yazar ora- } \\
\text { nının nispeten düşük olması }\end{array}$ & 0,03560 \\
\hline & & Sosyal medyada yaşanan yanlış yönlendirmeler ve bilgi kirliliği & $\mathbf{0 , 0 3 9 7 1}$ \\
\hline & & Sosyal medyaya yönelik güven eksikliği & 0,03335 \\
\hline & & $\begin{array}{l}\text { Toplumun önemli bir kesiminin ormanların giderek azaldığı algısına sahip } \\
\text { olması ve bu süreçte de orman teşkilatının payı olduğunu düşünmesi }\end{array}$ & 0,03431 \\
\hline
\end{tabular}


için, SWOT grupları ve her bir SWOT grubundaki SWOT faktörlerinin öncelik değerleri elde edilmiştir. Sonrasında temsilcilere ait bu öncelik değerlerinin aritmetik ortalamaları alınarak, SWOT grupları ve her bir SWOT grubu dahilindeki SWOT faktörleri için Tablo 7'de sunulan genel öncelik değerlerine ulaşılmıştır.

Tablo 7'deki genel öncelik değerleri incelendiğinde; bu çalışma sonucunda en yüksek önceliğe sahip SWOT grubunun, 0,25311 öncelik değeri ile "Tehditler/Tehlikeler" grubu olduğu ortaya çıkmıştır. Bunu sırasıyla 0,25155 öncelik değeri ile "Zayıflıklar" SWOT grubu ve 0,24902 öncelik değeri ile "Üstünlükler" SWOT grubunun takip ettiği anlaşılmaktadır. Buna karşın "Fırsatlar/Olanaklar" SWOT grubunun ise 0,24632 öncelik değeri ile diğer SWOT gruplarına göre nispeten düşük öneme sahip olduğu belirlenmiştir.

Her bir SWOT grubundaki SWOT faktörlerinin genel öncelik değerleri incelendiğinde; "Üstünlükler" SWOT grubu içerisinde yer alan "Orman teşkilatının ülkenin en ücra köşesine kadar örgütlenmiş olması" SWOT faktörü 0,03950 öncelik değeri alarak, en yüksek önceliğe sahip faktör olmuştur. Konuya "Zayıflıklar" SWOT grubu açısından yaklaşıldığında, bu grubun en yüksek öncelikli SWOT faktörünün 0,03889 öncelik değeri ile "İnsanların doğrudan bilgilendirilmemesinden kaynaklanan kulaktan dolma bilgilerle yanlış kanaatlere varllması" faktörü olduğu tespit edilmiştir. "Fırsatlar/ Olanaklar" SWOT grubundaki SWOT faktörleri ele alındığında; 0,03710 öncelik değerine sahip "Gelişen bilişim teknolojisi ile birlikte insanlara ulaşmayı kolaylaştıran medya araçlarının artma$s \imath$ " SWOT faktörü bu SWOT grubunun en yüksek öncelikli faktörü olmuştur. Nihayet "Tehditler/ Tehlikeler" SWOT grubunun en yüksek öncelikli SWOT faktörü ise 0,03869 öncelik değeri ile "Sosyal medyada yaşanan yanlış yönlendirmeler ve bilgi kirliliğ $i$ " faktörü olduğu görülmektedir.

\section{Tartışma ve Sonuç}

SWOT çözümlemeleri, içsel (üstünlükler ve zayıflıklar) ve dişsal (firsatlar ve tehditler) ortamların incelenmesini sağlamaktadır. SWOT çözümlemeleri sonucunda, strateji belirlemeyle en çok ilgili faktörlerin bir listesi elde edilmektedir. Bir başka ifadeyle SWOT çözümlemeleri, SWOT faktörlerinin genelde sadece kalitatif incelemesini içermektedir. SWOT faktörlerinin önemini (önceliğini, ağırlığını) sayısal olarak belirleme yeteneği yoktur. Oysa bir karar verme durumunda ve planlamada sayısal verilere ihtiyaç duyulmaktadır. Bu nedenle planlama sürecinde, SWOT çözümlemeleri etkin şekilde gerçekleştirilemez ve planlamada SWOT çözümlemelerinden yeterince faydalanılamaz.

Bu çalışmanın birinci bölümünde, SWOT çözümlemeleri ile ÇKKV tekniklerini bir araya getiren bir melez teknik olan R'WOT tekniği kullanılmıştır. Bu teknik SWOT gruplarının ve her bir SWOT grubu içindeki SWOT faktörlerinin öncelikleri ve önem sırasının belirlenmesinde, Siralama tekniği ve Doğrusal Kombinasyon tekniğini birlikte kullanan kombine bir yaklaşımdır.

Bir sektörün veya firmanın geleceği için en önemli içsel ve dişsal faktörler, SWOT çözümlemelerinde ortaya konmaktadır. R'WOT tekniğinde, dört SWOT grubu ve her bir gruptaki SWOT faktörlerine sayısal değerler verilmek suretiyle SWOT çözümlemeleri daha analitik hale getirilmektedir. R'WOT tekniği kullanımıyla, karar verici üstünlükler, zayıflıklar, fırsatlar ve tehditlerin sayısal değerlerinin ne olduğunu ortaya koymaktadır. Böylece bu teknik SWOT çözümlemelerinde kullanılan faktörler için sayısal öncelikler ortaya koymakta ve bu faktörleri ölçülebilir ve birbiriyle karşılaştırılabilir kılmaktadır.

SWOT çözümlemeleri tamamlandıktan ve R'WOT tekniğine dayalı olarak öncelikler belirlendikten sonra, toplanan bilgilerden faydalanmak önemlidir. Üstünlüklere dayalı olarak ve bunların tüm potansiyelini kullanarak hareket edilmelidir. Zayıflıkların ya taşıdığı riskler minimize edilmeli ya da bunların üstesinden gelecek şekilde üzerlerinde değişiklik yapılmalıdır. Zayıflıklar mümkün olduğunca üstünlüklere dönüştürülmelidir. Ardından sektörün önünde bulunan her firsattan yararlanması amaçlanmalıdır. Sonrasında amaçlara ulaşma yönünde mevcut tehditlerin farkında olunmalı ve bu tehditlerin firsatlara dönüştürülmesine çalışılmalıdir.

Böylece R'WOT tekniği kullanarak bir sektöre veya firmaya yönelik stratejilerin belirlenmesi ve önceliklendirilmesi sonucu, mevcut durumda ve gelecekte ne yapılacağı ve niçin yapılacağ 1 belirlenmekte ve ana faaliyetler tam olarak tanımlanabilmektedir. Bunun yanında gelişme yönünde en büyük avantajların neler olduğu ve hangi konularda değişiklik yapılmaya ihtiyaç duyulduğu da ortaya çıkmaktadır.

Sunulan R'WOT tekniği, farklı stratejik planlama durumları için uygun bir araçtır. Bu örnek uygulama çalışması da sunulan metodolojinin faydalılı̆̆ $1-$ n1 göstermiştir.

R'WOT tekniği ile hesaplama sürecine, ilgili tüm grupların katkısının alınması önemlidir. Zira farklı 
Tablo 7. "R’WOT Tekniğì” Çözümlemeleri Sonucunda Elde Edilen Genel Öncelikler

Table 7: General Priorities Obtained as a Result of "R'WOT Technique" Analysis

\begin{tabular}{|c|c|c|c|}
\hline $\begin{array}{l}\text { Swot } \\
\text { Gruplar1 }\end{array}$ & Öncelik & Swot Faktörleri & Öncelik \\
\hline \multirow{7}{*}{ Üstünlükler } & \multirow{7}{*}{0,24902} & $\begin{array}{l}\text { Orman bölge müdürlüklerinde basın ve halkla ilişsilerden sorumlu bir bi- } \\
\text { rimin bulunması }\end{array}$ & 0,03631 \\
\hline & & OGM bünyesinde Basın ve Halkla İlişkiler Müdürlüğü’nün bulunması & 0,03435 \\
\hline & & OGM’nin geçmişe dayalı köklü bir kurumsal kimliğe sahip olması & 0,03596 \\
\hline & & $\begin{array}{l}\text { Orman işletme müdürlüklerinin yapılan çalışmalar hakkında zaman zaman } \\
\text { orman köylülerine ve şehirde yaşayanlara faaliyetleri hakkında bilgi verme- } \\
\text { si ve onların görüşlerini alması }\end{array}$ & 0,03844 \\
\hline & & $\begin{array}{l}\text { Orman teşkilatı bünyesinde halkın kullandığı çok sayıdaki korunan alanda } \\
\text { hedef kitleye mesaj iletme imkânının bulunması }\end{array}$ & 0,03432 \\
\hline & & Orman teşkilatının ülkenin en ücra köşesine kadar örgütlenmiş olması & $\mathbf{0 , 0 3 9 5 0}$ \\
\hline & & $\begin{array}{l}\text { Ormancıl1k araştırma enstitüsü müdürlüklerinde halkla ilişkiler ve sosyal } \\
\text { ormancılık bölüm başmühendisliğinin bulunması }\end{array}$ & 0,03013 \\
\hline \multirow{7}{*}{ Zayıflıklar } & \multirow{7}{*}{0,25155} & Halkla ilişkiler konularında hizmet içi eğitimlerin yetersizliği & 0,03353 \\
\hline & & $\begin{array}{l}\text { İnsanların doğrudan bilgilendirilmemesinden kaynaklanan kulaktan } \\
\text { dolma bilgilerle yanlış kanaatlere varılması }\end{array}$ & $\mathbf{0 , 0 3 8 8 9}$ \\
\hline & & $\begin{array}{l}\text { OGM'nin kentte yaşayanlarla kurumsal iletişiminin yetersiz düzeyde kal- } \\
\text { mas1 }\end{array}$ & 0,03576 \\
\hline & & OGM'nin yaptı̆̆ 1 hizmetlerde alg1 yönetimine yeterince önem vermemesi & 0,03436 \\
\hline & & Orman işletme müdürlüklerinde halkla ilişkiler uzmanının bulunmaması & 0,03365 \\
\hline & & $\begin{array}{l}\text { Orman işletme şeflerinin halkla ilişkiler çalışmalarının sadece kişisel çaba- } \\
\text { larla sınırlı kalması }\end{array}$ & 0,03710 \\
\hline & & $\begin{array}{l}\text { Orman köylerinde halkla ilişkiler çalışmalarını yürütecek, konusunda uz- } \\
\text { man ve konuları halkın anlayacağı üslupta anlatabilecek elemanların azlığı }\end{array}$ & 0,03825 \\
\hline \multirow{7}{*}{$\begin{array}{l}\text { Firsatlar/ } \\
\text { Olanaklar }\end{array}$} & \multirow{7}{*}{0,24632} & $\begin{array}{l}\text { Gelişen bilişim teknolojisi ile birlikte insanlara ulaşmayı kolaylaştıran } \\
\text { medya araçlarının artması }\end{array}$ & $\mathbf{0 , 0 3 7 1 0}$ \\
\hline & & $\begin{array}{l}\text { Halkın bilgilendirilmesi ve bilinçlendirilmesini amaçlayan etkili sivil top- } \\
\text { lum kuruluşlarının varlığı }\end{array}$ & 0,03155 \\
\hline & & $\begin{array}{l}\text { Son yıllarda ülkemizde sesli ve görüntülü yayın organlarının çeşitlenip yay- } \\
\text { gınlaşması }\end{array}$ & 0,03589 \\
\hline & & Şehirleşme ile medya kullanım olanaklarının artması & 0,03383 \\
\hline & & Toplumda çevre bilincinin artması & 0,03673 \\
\hline & & Toplumda eğitim düzeyi artması & 0,03668 \\
\hline & & Toplumun sosyo-ekonomik olarak gelişmesi & 0,03454 \\
\hline \multirow{7}{*}{$\begin{array}{l}\text { Tehditler/ } \\
\text { Tehlikeler }\end{array}$} & \multirow{7}{*}{0,25311} & $\begin{array}{l}\text { Gelişmiş bölgelerde karşılaştırıldığında kırsal bölgede kitle iletişim araçları } \\
\text { kullanım kültürünün zayıflığı }\end{array}$ & 0,03353 \\
\hline & & Halkın çevre bilincinin yeterli düzeyde olmaması & 0,03835 \\
\hline & & $\begin{array}{l}\text { Orman içinde veya bitişiğinde yaşayan köylülerin sosyo-ekonomik neden- } \\
\text { lerle ormana bağımlılıklarının fazla olması }\end{array}$ & 0,03486 \\
\hline & & $\begin{array}{l}\text { Orman idaresinin en çok ilişkide olduğu orman köylerinde okur-yazar ora- } \\
\text { nının nispeten düşük olması }\end{array}$ & 0,03615 \\
\hline & & Sosyal medyada yaşanan yanlış yönlendirmeler ve bilgi kirliliği & $\mathbf{0 , 0 3 8 6 9}$ \\
\hline & & Sosyal medyaya yönelik güven eksikliği & 0,03673 \\
\hline & & $\begin{array}{l}\text { Toplumun önemli bir kesiminin ormanların giderek azaldığı algısına sahip } \\
\text { olması ve bu süreçte de orman teşkilatının payı olduğunu düşünmesi }\end{array}$ & 0,03480 \\
\hline
\end{tabular}


gruplara ait olası farklı bakış açıları, sağlıklı sonuçlar alabilmek açısından faydalı olabilir.

SWOT çözümlemeleri ve ardından R'WOT tekniği uygulamaları sadece bir kez yapılıp, gelecekte bir daha tekrar edilmemezlik yapılmamalıdır. Sektörün bulunduğu ortam zaman içerisinde sürekli değişeceği için bu çözümlemenin de sektör için sürekli bir uygulama olması gereklidir.

$\mathrm{Bu}$ çalışmada mevcut üstünlükler, zayıflıklar, firsatlar ve tehditler ortaya konularak, Isparta OBM'deki ormancılık çalışmalarını kamuoyuna duyuracak etkili kitle iletişim araçlarının belirlenmesi ve önceliklendirilmesi işlemi gerçekleştirilmiştir. Böylece bu alandaki kitle iletişim araçlarının geliştirilmesine yönelik öneriler geliştirmiştir.

Yapılan SWOT Çözümlemeleri bu araştırma alanında kitle iletişim araçlarının potansiyelinin yüksek olduğunu ortaya koymaktadır. Nitekim bu araştırma alanının özellikle orman teşkilatının ülkenin en ücra köşesine kadar örgütlenmiş olmas1, orman işletme müdürlüklerinin yapılan çalışmalar hakkında zaman zaman orman köylülerine ve şehirde yaşayanlara faaliyetleri hakkında bilgi vermesi ve onların görüşlerini alması, OGM bünyesinde basın ve halkla ilişkiler müdürlüğünün bulunması, orman bölge müdürlüğünde basın ve halkla ilişkilerden sorumlu bir birimin bulunmas1, OGM'nin geçmişe dayalı köklü bir kurumsal kimliğe sahip olması, Orman teşkilatı bünyesinde halkın kullandığı çok sayıdaki korunan alanda hedef kitleye mesaj iletme imkânının bulunması ve ormancılık araştırma enstitüsü müdürlüklerinde halkla ilişkiler ve sosyal ormancılık bölüm başmühendisliğinin bulunması gibi özellikleri “üstünlükler” kapsamında sayılabilecek özellikleridir.

Araştırma alanındaki kitle iletişim araçlarının geliştirilmesine yönelik stratejilerde, yukarıda sayılan bu güçlü yanlardan tam olarak faydalanmalı ve daha da geliştirilmesine çalışılmalıdır.

Isparta OBM'de kitle iletişim araçlarının gelişimini zorlaştırıcı bazı "zayıflıklar" da vardır. Bu kapsamda insanların doğrudan bilgilendirilmemesinden kaynaklanan kulaktan dolma bilgilerle yanlış kanaatlere varılması, orman köylerinde halkla ilişkiler çalışmalarını yürütecek, konusunda uzman ve konuları halkın anlayacağı üslupta anlatabilecek elemanların azlığı, orman işletme şeflerinin halkla ilişkiler çalışmalarının sadece kişisel çabalarla sınırlı kalması, OGM'nin yaptığı hizmetlerde alg1 yönetimine yeterince önem vermemesi, OGM'nin kentte yaşayanlarla kurumsal iletişiminin yetersiz düzeyde kalması, orman işletme müdürlüklerinde halkla ilişkiler uzmanının bulunmaması ve halkla ilişkiler konularında hizmet içi eğitimlerin yetersizliği önem taşımaktadır.

Araştırma alanına ait kitle iletişim araçları stratejilerinde tüm bu olumsuzlukların bilincinde olunma1, yok edilmesine çalışılmalı veya taşıdıkları riskler minimize edilmelidir. Böylece her bir zayıflığın üstünlüğe dönüştürülmesi yolları aranmalıdır.

Araştırma alanı kitle iletişim araçlarının gelişimi yönünden pek çok "fırsatlara" da sahiptir. Nitekim gelişen bilişim teknolojisi ile birlikte insanlara ulaşmayı kolaylaştıran medya araçlarının artması, toplumda çevre bilincinin artması, toplumda eğitim düzeyi artması, son yıllarda ülkemizde sesli ve görüntülü yayın organlarının çeşitlenip yaygınlaşması, toplumun sosyo-ekonomik olarak gelişmesi, şehirleşme ile medya kullanım olanaklarının artması ve halkın bilgilendirilmesi ve bilinçlendirilmesini amaçlayan etkili sivil toplum kuruluşlarının varlığı en önde gelen avantajlardır.

Isparta OBM'deki kitle iletişim araçları stratejilerinde geliştirilmeye değer tüm bu durumlar değerlendirilmeli ve bunlardan yararlanılmaya çalışılmalıdir.

Öte yandan araştırma alanlarının kitle iletişim araçları gelişimi yönünde karşı karşıya bulunduğ baz1 "tehditler" de bulunmaktadır. Bunlardan önem taşıyanları sıralamak gerekirse; sosyal medyada yaşanan yanlış yönlendirmeler ve bilgi kirlili$\breve{g}$ i, halkın çevre bilincinin yeterli düzeyde olmamas1, sosyal medyaya yönelik güven eksikliği, orman idaresinin en çok ilişkide olduğu orman köylerinde okur-yazar oranının nispeten düşük olması, orman içinde veya bitişiğinde yaşayan köylülerin sosyoekonomik nedenlerle ormana bağımlılıklarının fazla olmas1, toplumun önemli bir kesiminin ormanların giderek azaldığ 1 algısına sahip olması ve bu süreçte de orman teşkilatının payı olduğunu düşünmesi ve gelişmiş bölgelerde karşılaştırıldığında kırsal bölgede kitle iletişism araçları kullanım kültürünün zayıflığı konusudur.

Isparta OBM'deki kitle iletişim araçları stratejilerinde yukarıda belirtilen tüm bu tehditler göz önünde bulundurulmalı, kitle iletişim araçları gelişimini olumsuz etkileyecek bu durumlardan kaçınılmalı ve her bir tehdidin bir firsata dönüştürülmesine çalışılmalıdır.

\section{Teşekkür}

Bu makale, T.C. Tarım ve Orman Bakanlığı, Batı Akdeniz Ormancılık Araştırma Enstitüsü Müdürlüğünce "Ormancılık Çalışmalarını Kamuoyuna Duyuracak Etkili Kitle İletişim Araçlarının Belirlenmesi (Isparta OBM Örneği)" adıyla ve 
19.8501/2019-2020 proje numarasıyla gerçekleştirilen araştırma sonucunda hazırlanan ve OGM Araştırma İhtisas Grupları Toplantısında yayınlanmas1 yönünde karar verilen Proje Sonuç Raporunun (Y1lmaz ve ark., 2020) bir bölümünün özetidir.

\section{Kaynaklar}

Anonim, 2004. Ulusal ormanc1lik program1 (20042023). TC Orman Bakanlığ 1,90 sayfa, Ankara.

Anonim, 2014. Sürdürülebilir Orman Yönetimi, Özel İhtisas Komisyonu Raporu. Kalkınma Bakanlığ1, Onuncu Kalkınma Planı 2014-2018, 86 sayfa, Ankara.

Erol, S. Y., 2012. Çevre politikası aracı olarak eğitim ve bilinçlendirme çalışmaları ve Akdeniz bölgesi için işlevsel önemi. KSÜ Doğa Bilimleri Dergisi, Özel Sayı, s. 185-192, Kahramanmaraş.

Y1lmaz, E., Alkan, S., Kayacan, A., Bayir, Y., 2020: Ormancılık çalışmalarını kamuoyuna duyuracak etkili kitle iletişim araçlarının belirlenmesi (Isparta
OBM örneği). T.C. Tarım ve Orman Bakanlı̆̆ı, Batı Akdeniz Ormancılık Araştırma Enstitüsü Müdürlüğü, Sonuçlanan Proje Sonuç Raporu, 70 sayfa, Antalya.

OGM, 2008. Basın-halkla ilişkiler ve tanıtım büroları tamimi. Tamim No: 6552, Ankara.

OGM, 2016. Stratejik plan 2017-2021. 80 s., Ankara.

Sönmezler, G., 2008. Proje yönetimi yaklaşımıyla en iyi festival mekanı ve içeriğinin seçimi. Yıldız Teknik Üniversitesi, Makine Fakültesi, Endüstri Mühendisliği Bölümü, 149 sayfa, İstanbul.

UNICEF, 1989: UNICEF'in Çocuk Haklarına Dair sözleşmesi. UNICEF Türkiye Milli Komitesi, Ankara.

Yılmaz, E., 2006. R'WOT tekniği: arıcılık sektöründe katılımcı yaklaşım ile örnek bir uygulaması. T.C. Çevre ve Orman Bakanlığı, Doğu Akdeniz Ormancılık Araştırma Müdürlüğü, Çevre ve Orman Bakanlığı Yayın No: 274, DOA Yayın No: 40, Çeşitli Yayın No: 6, 93 sayfa, Tarsus. 